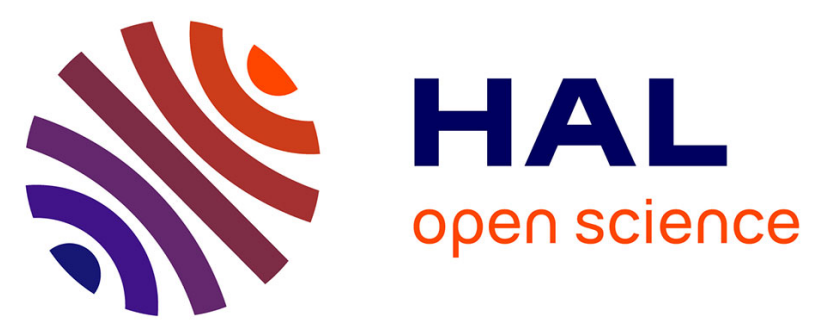

\title{
Spanish Civil War Commemorations in Northern Ireland, The Republic of Ireland And Spain: Political, Spatial And Generational Relations Between Irish Anti-Fascists And Spanish Historical Memory Activists
}

Daniel Meharg

\section{To cite this version:}

Daniel Meharg. Spanish Civil War Commemorations in Northern Ireland, The Republic of Ireland And Spain: Political, Spatial And Generational Relations Between Irish Anti-Fascists And Spanish Historical Memory Activists. European Journal of English Studies, In press. hal-02984739

\author{
HAL Id: hal-02984739 \\ https://hal.science/hal-02984739
}

Submitted on 31 Oct 2020

HAL is a multi-disciplinary open access archive for the deposit and dissemination of scientific research documents, whether they are published or not. The documents may come from teaching and research institutions in France or abroad, or from public or private research centers.
L'archive ouverte pluridisciplinaire HAL, est destinée au dépôt et à la diffusion de documents scientifiques de niveau recherche, publiés ou non, émanant des établissements d'enseignement et de recherche français ou étrangers, des laboratoires publics ou privés. 
Daniel Meharga

a Département du Monde Anglophone, Université Sorbonne Nouvelle - Paris 3, France daniel.meharg@sorbonne-nouvelle.fr

ORCID ID: 0000-0002-6729-1338

Daniel Meharg is an Irish PhD candidate at the Université Sorbonne Nouvelle, Paris, supervised by Irish studies specialists Wesley Hutchinson and Clíona Ní Ríordáin. During a Masters year in Madrid, he met a number of members of the Friends of the International Brigades Ireland. He has travelled to Limerick, Dublin, Belfast and elsewhere in Ireland several times since 2017 to understand recent developments in the Irish memory of the Spanish civil war through participant observation of events, interviews, personal and newspaper archives and works of literature.

Keywords: Friends of the International Brigades Ireland; Spanish Civil War; memory; commemoration; Belfast; Dublin; republicanism; anti-fascism; cross-community reconciliation

\begin{abstract}
:
This article attempts to analyse the distinctive nature of the commemorations of the Spanish Civil War that have been taking place in the North and the Republic of Ireland, and the partnerships of the memorial groups with Spanish correspondents. Using press archives and interviews, I argue that the commemorations are part of a delayed process of recovery of Ireland's historical memory of people who were often exiled or forgotten, as well as a contribution to cross-community reconciliation in Northern Ireland. This process of rediscovery takes place through the creation of lieux de mémoire in the form of plaques, stone monuments of various forms, artworks, murals and repeated commemorations across Ireland and Spain. Although this process has its roots in Irish republican groups, trade union and community activists, it has expanded sufficiently to attract attention in Spain and to put down roots in the Madrid area and in Catalonia, most notably through regular visits by the Friends of the International Brigades Ireland group. The commemorations seem to remain more informal than in the United Kingdom, perhaps reflecting their recent development in the wake of the allconsuming Troubles that previously left less space for such activities.
\end{abstract}


Daniel Meharg

Spanish Civil War Commemorations in Northern Ireland, The Republic of Ireland And Spain: Political, Spatial And Generational Relations Between Irish AntiFascists And Spanish Historical Memory Activists

In March 2019, Friends of the International Brigades Ireland (FIBI) organised an event in a community hall belonging to the Corduff Gaels GAA club, at a country crossroads near Castleblayney, Co. Monaghan. More than 200 participants packed the hall to hear long-time FIBI members Eddie O’Neill and Gearoid Ó Machail, local historian Bernie Ruth, councillor Xavier Galcerà Adell and historian Aitor Garcia Solé from the Catalan town of Batea document the story of John Finnegan, who had left the townland of Lios an Chuilinn (Lisacullion), emigrated to Canada, then joined the International Brigades and died in the Spanish Civil War. This came after O’Neill and other FIBI members spent weeks searching the digitised RGASPI archives (the Moscow Comintern archives of the International Brigades) and a long period collaborating and corresponding with their Catalan contacts, including Xavier Galcerà Adell and Aitor Garcia Solé who had been searching the battlefields of the Ebro, west of Barcelona. The event attracted FIBI members and sympathisers from all over Ireland, but also many locals who were curious to find out about a long-lost son of the area, whose house became associated with a whole new life story of a forgotten emigrant son. John Finnegan's nondescript house itself was pointed out to FIBI members from our bus ${ }^{1}$ by Ó Machail and O’Neill on the way to the event, and the first commemorative walk in memory of John Finnegan took place there on $21^{\text {st }}$ June 2019.

The whole process echoes what Gérard Noiriel described as the uncovering of a 'nonlieu de mémoire’ in his seminal book Le Creuset Français (1988) and in other articles, a term he used to criticise phenomena of collective amnesia and erasures of aspects of history that are rediscovered generations later.

L'affaire d'Aigues-Mortes illustre au plus haut point ce que j'ai appelé dans le Creuset français les «non-lieux de mémoire » de l’histoire républicaine. Le «pogrom» et le déni de justice qui l’a suivi ont été refoulés de la mémoire nationale, mais aussi de la mémoire locale. Le travail collectif de «repentance» n’ayant pas pu se faire, un sentiment diffus de culpabilité subsiste encore aujourd'hui à AiguesMortes, comme j’ai pu le constater en enquêtant sur place. (Noiriel 2010, 2 ) $^{2}$ 
Whereas Noiriel wrote about the 1893 massacre of Italian immigrants in Aigues-Mortes, FIBI's commemorations aim to remind Ireland of its forgotten members of the International Brigades. A patchwork of linked local groups have installed plaques and organised small events across the North and the Republic in memory of that group of about 250-330 people (depending on sources and counting methods), many of whom were once socially ostracised and forced to emigrate from the country because of their politics and to find work. Whereas Noiriel wrote about immigrants being erased from the public consciousness, Irish groups north and south are memorialising emigrants who were erased. Unlike in Great Britain, where International Brigade veterans organised into the International Brigades Association (and subsequently the International Brigade Memorial Trust, or IBMT) within the orbit of the trade union movement and the Labour Party, Irish veterans were unable to work within trade unions, run for office or be active politically without attracting red scare tactics. Irish International Brigade veterans only organised their first public commemoration in 1979, when they repatriated their leader Frank Ryan's remains from Dresden. The Irish political context had become more favourable than in the tense 1930s, arguably helped by the demise of Franco, the island's entry into the European Economic Community, the influences of globalisation, and the growth of human rights campaigns such as those against South African apartheid and in support of the Nicaraguan Sandinistas.

Their acts of remembrance carry echoes of Pierre Nora's conceptualisation of the birth of 'lieux de mémoire', especially as many of the commemorations are repeated multiple times, or annually.

Lieux de mémoire originate with the sense that there is no spontaneous memory, that we must deliberately create archives, maintain anniversaries, organise celebrations, pronounce eulogies, and notarise bills because such activities no longer occur naturally. (Nora 1989, 12)

Commemorations of the Spanish Civil War in Ireland have been run by a wide variety of local groups, stepping back from national history to uncover less-known local figures such as Finnegan, and tying the International Brigades to contemporary labour and social struggles. Over 36 works of art, memorial plaques and small monuments have been documented in every corner of the island, including 12 in the Belfast area and 7 in Dublin. ${ }^{3}$ With the $80^{\text {th }}$ anniversary of the civil war from 2016 to 2019, there has been a wave of activity across Europe, including striking new initiatives such as the Clare International Brigades Memorial Trust in Ireland 
(created in Ennis in 2016), the French Association du 24 août 1944 (founded in Paris in 2014, focused on both the civil war and the Spanish veterans of the Division Leclerc) and the shortlived Associació Museu Internacional de la Guerra Civil Espanyola, founded in Barcelona in 2016 to organise the creation of Spain’s first national museum about the history of the country's civil war. ${ }^{4}$

In this article I hope to focus on the nature of current Spanish Civil War commemorations and memorial groups in Northern Ireland and border areas, from the perspective of their strong local roots despite political heterogeneity; their varying forms of spatial inscription in many - often marginal - parts of Northern Ireland, the Republic of Ireland and Spain; and finally the technological changes that have both facilitated their development and their interaction with Spanish memorial associations, while hinting at the impermanence of Internet-based forms of memorialisation.

Using press archives, documents produced by Irish memorial associations and interviews, I will attempt to understand the hyperlocal nature of Irish commemorations, how they frame the Irish contribution to the International Brigades, and how the people organising these commemorations have evolved over the last 40 years.

\section{A decentralised anti-fascist memory with deep local roots}

A striking characteristic of the Irish commemorations is their deep attachment to localities, especially to the 'home-place' (townland) of origin, of some of the more commemorated Brigaders such as John Finnegan (Castleblayney), Charlie Donnelly (Dungannon), Tommy Patten (Achill), Peter Daly (Wexford) and Peter O’Connor (Waterford). In his interview with me, Gearoid Ó Machail described FIBI as a relatively informal network based around personal affinities and a small mailing list. It started out in 1986 as a small group of left-wing republicans and activists from Dungannon (Co. Tyrone) named the Friends of Charlie Donnelly, after the young Irish socialist poet of that name, killed in the battle of Jarama in Spain on $27^{\text {th }}$ February 1937 . The group has organised a two-day 'Charlie Donnelly Winter School' annually or biannually in February or March since at least 2001, in the area where Donnelly grew up, occasionally visiting his house; a small stone monument was installed in his memory there in 2003 (O’Connor, 2008). In our recent interview, Ó Machail described his first years: 
I first made contact with the Friends of Charlie Donnelly group at a Charlie Donnelly Winter School in Dungannon in 2006. ${ }^{5}$ I merely attended as an audience member that first year but was impressed with the performance of Mick O’Reilly from the ITGWU and David Ervine of the PUP at a discussion panel event as part of the School. The following year when I attended, I recognised a number of the individuals participating at the school including International Brigade veteran Bob Doyle, Bernadette McAliskey and Martin McGuinness, but knew little of the organising group’s work at that stage. Harry Owens and Bob Doyle’s Brigadista book had just been published and I was honoured to receive a signed copy and to be photographed with Bob for the first time. I was attracted by the strong left wing and socialist republican content of the school and made a decision to make contact with members and to volunteer my assistance with the group.

The Charlie Donnelly Winter Schools include commemorations of local participants in the International Brigades, conferences on local political and historical topics from a wide range of attendees and concerts by local musicians. Typically the 2019 programme (available on FIBI's website) included presentations by O’Neill and the chair of the Corduff/ Raferagh Heritage group, Bernie Ruth, who recounted what they had discovered about John Finnegan, then unveiled a plaque in Irish, Catalan and English (in that order) to 'John Finnegan, Lios an Chuilinn, Machaire Rois, Co Mhuineachán.’ The plaque featured a small International Brigades flag and a version of the (green and yellow) starry plough flag used by the Irish Citizen Army of James Connolly in 1916. Historian Aitor Garcia Solé and councillor Xavier Galcerà Adell from Batea, Catalonia, explained the archaeological digs undertaken under the guidance of the Consorcio Memorial Espacios de la Batalla del Ebro, during which they confirmed the death of John Finnegan in the area, where he was fighting in a unit of the Canadian Mackenzie-Papineau battalion of the $15^{\text {th }}$ International Brigade. Their speeches were followed by a meal and music by a local Irish and French traditional music ensemble, then a short bus journey to a previously installed FIBI plaque in Augnacloy, Co. Tyrone, where the group gathered to take photographs at a memorial (installed in 2013) to local International Brigader Ben Murray. The group then proceeded to the old industrial village of Caledon for a number of lectures, on the 'Caledon Lockout' of 1917 by historian Fearghal Mac Bhloscaidh, 'Social Justice and the Democratic Deficit’ by former 1981 Irish National Liberation Army hunger striker Tommy McKearney and Presbyterian Rev. Tony Davidson, and ‘The Legacy of Peadar O’Donnell’ by O’Donnell’s literary executor Dónal Donnelly, all of which firmly anchored the Winter School into local 
activist and labour history networks. Another stop for photographs took place at the Dungannon Charlie Donnelly memorial monument, built in 2003, before a short concert by musician, activist and FIBI and IBCC $^{6}$ member Pól MacAdaim from Belfast in a local pub.

One of the first Irish plaques was installed in 1984 on Achill Island in the remote west, in memory of Tommy Patten who fell in Madrid in December 1936, by Séan Fitzpatrick of the National Graves Association alongside veterans Peter O'Connor, Michael O'Riordan, and 400 sympathisers (de Bréadún 1986). O’Riordan, the perennial leader of Ireland’s Communist Party, had helped to set in motion a unique process of inscription of Spanish Civil War memory into the Irish space, across trade union offices, republican plots and public spaces, by repatriating the body of the Irish group’s leader Frank Ryan in 1979. However, the commemorations were never restricted to the Communist Party: many Brigaders had started out their lives as Irish Republican Army (IRA) volunteers in the 1930s, or even during the Irish civil war, and had been part of the Republican Congress group that left the IRA in 1934 with Frank Ryan, George Gilmore and Peadar O’Donnell.

One political figure who, unusually for politicians of his generation, has shown consistent interest in the International Brigades and attended the 1984 event during his time as a left-wing Labour Party senator was Michael D. Higgins. In a 2016 speech at the AGM of the London-based IBMT in Dublin, he compared the decentralised Irish commemorations of Spain with Ireland's Decade of Centenaries, emphasising the political similarities in the idealism of those who fought in both periods, rather than the differences between memorial activities carried out by the Irish state and those carried out by smaller political groups more at liberty to pursue their own ideological interests rather than attempt to speak to the entire country.

If we are to tackle the growing divisions within the international community it is important that we focus our efforts anew on building social cohesion and solidarity. In the centenary year of the republican uprising of 1916, and the 80th anniversary of fascism's attack on the Spanish Republic, we should recall the origins and aims of true republicanism, and strive to continue to show the strength of conviction, moral courage and generosity that was shared among those who fought in the International Brigades. (President of Ireland 2016)

His comments on 'true republicanism' seem to attribute the value of commemorations to their effect on those who would look back on 1916 and 1936 and renew the ideals on which their current activism and activity would be based, echoing the frequent references to James 
Connolly expressed in Irish commemorations of the Spanish Civil War.

Indeed, the decentralised, localised nature of the memorial activities around the Spanish Civil War in Ireland stand in contrast to the Irish government's coordination of its Decade of Centenaries since 2012, a hotly debated process of remembering the years leading up to Ireland's independence, under the guidance of an Expert Advisory Group on Commemorations that reports to the Department of the Taoiseach. According to its dedicated website, it advises the government on historical matters relating to the Decade of Centenaries, and consults with voluntary, community and academic groups to ensure proportionate and appropriate commemorations for the many controversial events of the 1912-1923 period. While this organisational format attempts to preclude actual government control over the content of the events themselves, the funding is allocated and distributed by Dublin.

Every local authority in the country is to receive $€ 10,000$ each to mark the War of Independence and Civil War. The money is intended to replicate the success of the Easter Rising centenary where local authorities co-ordinated commemorations in each county. Most of the 3,500 events which occurred to mark the Easter Rising centenary in 2016 were organised by communities overseen by the local authorities. The allocation follows on from the recommendation of the expert advisory group on commemorations about the second half of the Decade of Centenaries. (McGreevy 2019)

This contrasts with the more ad hoc nature of the funding of the Spanish Civil War commemoration groups. Ó Machail, for example, emphasised that FIBI remains independent from outside influence by restricting themselves to member-driven fundraising activities. Initially, as a small group from the border area of Northern Ireland, this was relatively straightforward, but as the organisation grew, membership of the mailing list, the backbone of the organisation, became conditional on a membership fee which covered the running costs. For the core members, the organisational strain of taking up to 150 people to the commemorations of the Battle of Jarama (Rivas-Vaciamadrid, Spain) every February since 2007, alongside a number of other journeys to Spain and events in Ireland, had begun to cause problems of scale and make fundraising complex. In Ó Machail’s words,

As FIBI has expanded very rapidly in recent years, in terms of reach, influence and overall output, the small core of committed activists at the helm has struggled with the pressures of an ever-increasing workload, a growing affiliate membership and 
our desire to remain as a non-formalised and decentralised structure with an ad-hoc, but nonetheless effective approach, to strategic activism.

In effect, FIBI restricts itself to coordinating the calendar of events around repeat commemorations and occasionally new findings such as John Finnegan. Typically, their 2017 Charlie Donnelly Winter School lasted for three days, with international delegates from Madrid and speakers and political representatives from across the island of Ireland and from Scotland, and gathered support from a variety of interested local stakeholders.

We could not have done it without the solidarity and financial input of other organisations in the community and cultural relations sector with whom we have fraternal relations. We also received formal support from Mid Ulster Council. FIBI itself has limited resources and could not flourish without the support and logistical help of other activist groups in the local community. (Ó Machail 2019 interview)

In their view, this organisational choice offers them the freedom and flexibility to organise ad hoc commemoration events without straying from their socialist republican ideas, avoiding the more drawn-out process of requesting funds from institutions such as the Northern Ireland Community Relations Council, which the Belfast International Brigade Commemoration Committee has used in some occasions. Using the IBCC's memorial booklet from 2015, Civil War in Spain: A Time of Heroes, which documents many of the IBCC's activities from 2005 to 2015, we will compare the two organisations that operate in the North of Ireland.

\section{Spatial and graphical inscriptions of links between (Northern) Irish and Spanish anti- fascist memorial groups.}

Despite the popularity in Ireland of the Christy Moore song 'Viva la Quinta Brigada', originally written in 1983 and based on the contents of Michael O’Riordan's Connolly Column (1979), the spatial inscription of Spanish Civil War memory in Ireland is a recent phenomenon. Only ten of the various plaques and monuments currently installed around the island were in place before 2000, and only four before 1990; at least 16 plaques and stone monuments of various sizes have been installed since 2010, out of a total of 48 listed on the IBMT website. In comparison, there are about 122 (often older) plaques and memorials spread across Great Britain, for a population around ten times larger, suggesting a surge in interest in the memory 
of the Brigades in the twilight years of the last Irish veterans (Michael O’Riordan died in 2006, Bob Doyle in 2009). O’Riordan and Doyle were particularly active in their final years and are best remembered by activists due to their longevity.

Since 2007, FIBI has been expanding beyond Tyrone, organising local commemorations in Dundalk and Dublin but also visiting and collaborating with memorial groups in Spain, including the Madrid-based Asociación de Amigos de las Brigadas Internacionales (AABI), the towns of Rivas-Vaciamadrid (near Madrid) and Batea (near the Ebro) and occasionally other localities in the Basque country or Andalucía. From an Irish point of view, International Brigade veteran Bob Doyle had a key role in initiating exchanges with Spain, campaigning successfully in the early 1990s to force the Madrid regional government to retrieve the remains of his comrades from a cemetery rubbish dump in Morata de Tajuña and give them a proper burial. He developed a large network of contacts among veterans, their relatives and supporters, described in his memoir Brigadista (2006) written with the trade unionist and historian Harry Owens, including support from a number of French International Brigade veterans and letters from ex-Tanáiste Dick Spring and former Prime Minister Edward Heath. In their interviews with me, FIBI members Gerard Murray (from the Teach na Fáilte Irish Republican exprisoners' support group), Ó Machail and O’Neill all cited Doyle as an inspiration for their current commemorative work and political activity, having first met him at the 2007 Charlie Donnelly Winter School in Dungannon.

FIBI found in Rivas-Vaciamadrid a town council run by Izquierda Unida and heavily invested in collaborating with the AABI, which was originally launched in 1995 to commemorate the $60^{\text {th }}$ anniversary of the International Brigades' creation in 1996 and to obtain Spanish nationality for the surviving veterans. In 2010, as the Friends of Charlie Donnelly, they completed a memorial to Charlie Donnelly and the other Irish members of the International Brigades. An uncredited report in the Andersonstown News (2010) described the small monument, a large rock set upright upon a cairn of 32 stones representing the 32 counties of Ireland.

The remainder of the stones for the cairn were then collected from the battlefield and were built to envelope the Irish stones in an attempt to signify how the Spanish hold dear those Irishmen who gave their lives. This was a difficult task to be carried out within days, but it was helped enormously by the goodwill of the council workers of Rivas Vaciamadrid and locals. 
Speakers included Ángeles Maestro, a former Izquierda Unida member of the Spanish parliament who had worked to obtain Spanish citizenship for the surviving veterans of the International Brigades in 1996, AABI president Isabel Pinar, Barry Monteith, former mayor of Dungannon, Irish ambassador to Spain Justin Harman, and four local residents who had lived through the civil war and dictatorship. The inauguration was followed by the $3^{\text {rd }}$ edition of the Marcha del Jarama, a commemorative walk across parts of the Jarama battlefield that was first organised by Doyle, Owens and AABI historian Severiano Montero in 2003.

The regular Irish visits by Doyle and Owens (from 1991 to 2009) and Friends of Charlie Donnelly/ FIBI (since 2007) together with their creation of the Charlie Donnelly monument which has acted as a focal point, have created a large amount of goodwill toward the Irish (and British) in Rivas-Vaciamadrid, helped further by the presence of 120 FIBI members and 50 (Scottish, English and Welsh) IBMT members at the $10^{\text {th }}$ Marcha del Jarama in 2017. Many of them had attended every year since 2007. José Manuel Castro Fernandez, a Rivas-Vaciamadrid town councillor and member of Jarama80, the coordinating committee for the 2017 commemoration of the $80^{\text {th }}$ anniversary of the Battle of Jarama, expresses this goodwill in terms of the beneficial effect for the town of having visiting foreigners who see value in Spain’s recent history.

La relación con los irlandeses es muy buena porque es un trabajo que ayuda al pueblo de Rivas. No solo es un recuerdo a Charlie y a los Brigadas Internacionales, pero también es un punto de interés para la ciudadanía y para el turismo, para decirlo de alguna manera. También por esa colaboración, FIBI ayuda el ayuntamiento a participar en una escuela de formación en el 2017, y yo fui como representante del ayuntamiento a [esta] escuela Charlie Donnelly. ${ }^{7}$

Relations between FIBI and Rivas-Vaciamadrid were helped enormously by the work inside AABI of a dual nationality Irish-Spanish member and organiser, E.R., interviewed in February 2019, who quickly acquired a protean role, 'beyond that of translator and interpreter, it was some kind of cultural mediation, [to] bridge the gap between the two cultures and the two languages.' Beyond Harry Owens, a hispanist who had been a member of AABI since its foundation, few FIBI members initially spoke much Spanish. E.R.'s case suggests a unique empathy among the Irish for the Spanish Republican silence, born from years of defeat and repression under the Franco dictatorship. 
I come from a left family, my grand uncle was an International Brigader, he came from outside Cavan, we never had evidence but my mother had heard of it when she was young, only it was one of those stories that was always silenced in De Valera's Ireland, it was very oppressive and repressive... Catholicism was imposed on the society of the time... He enlisted with his mother's maiden name: Peter B. but his real name was Eddie V.... To this day it’s only his eldest son, also [named] Eddie V., says he was in the International Brigades; the other younger siblings deny it completely. The stigma goes on, a generation after. ${ }^{8}$

In a September 2018 interview with Ciaran Crossey, Chair of the Belfast IBCC, he suggested that the Good Friday Agreement could have contributed to the rise in interest in the International Brigades in Ireland. Indeed, the IRA and INLA ceasefires and the end of the armed conflict in the 1990s created a space for republican (and loyalist) paramilitary volunteers and activists to engage in commemorative activity around working-class history in their areas.

It's one of the things that the retired political groups do, they've moved away from less constructive things, that's the way I'll put it. They're now occupying their time with community politics, commemorations, it keeps people busy. It's an element of politics. Like the IRSP ${ }^{9}$, they're involved because they see themselves as a left republican group, so therefore they want that logical connection to the people in the 30s, the antifascist struggle then, the antifascist struggle today.

News of this proliferation reached Madrid in artistic form in 2017, after punk band Boikot went to Ireland to film footage for a video clip commemorating the battle of Jarama, and told Spanish news website Público.es that 'just in Belfast there were more memorials to the International Brigades than in the whole of Spain' (Campelo 2017). While this may be slightly exaggerated, it suggests a much higher level of openness around Spanish Civil War commemoration in Ireland than in Spain, which surprised the leftwing band. Their resulting music video (Boikot 2017) was a fascinating combination of images from Northern Ireland and Spain and a unique piece of intercultural dialogue, although also a somewhat idealistic view of Northern Irish politics. Footage of band members visiting Spanish Civil War-related plaques, tombstones and murals in Belfast was interspersed with drone footage of the band playing on a clifftop opposite Dunluce Castle (Co. Antrim), together with scenes from a re-enactment of the battle of Jarama, with young Spanish people playing Irish International Brigade members 
Charlie Donnelly and Peter O’Connor (who visited Spain multiple times alongside Doyle before his death in Waterford in 1999). The music video was accompanied by an extended short film re-enacting the Battle of Jarama through the eyes of a Republican soldier who alternately hallucinates that he is on stage with Boikot in 2017, and that he finds himself back on the battlefield with Donnelly and O’Connor. In the closing credits, Donnelly is described as

a young promise of Irish literature, [who] described his own end prophetically in the tragic poem 'The Tolerance of the Crows'. Now the poet forms part (sic) of the glorious and numerous group of selfless heroes that forged the legend of the International Brigades.

The re-enactment short film was screened before several hundred attendees at the main commemoration event of the battle of Jarama in Rivas-Vaciamadrid in 2017, while the music video was promoted online. Intriguingly, they did not show any footage of a large stained-glass window to the International Brigades in Belfast City Hall that had been freshly installed by the IBCC less than two years before. This could suggest that their visit was organised in contact with a member of FIBI or the Teach na Fáilte IRSP-linked group rather than a member of the IBCC.

The IBCC's explicitly cross-community approach to Spanish Civil War commemoration differs from FIBI's emphasis on anti-fascist heritage in a number of ways, first and foremost because of the strong local roots of its members and partners across a spectrum of Catholic and Protestant areas of West, North and East Belfast, in contrast to FIBI which has more ties to Irish-language groups and operates on a cross-border basis in counties Tyrone, Armagh, Louth, Dublin and elsewhere. Its 2015 booklet Civil War in Spain: A Time of Heroes (IBCC 2015) indicates it is based out of the Belfast Unemployed Resource Centre, a trade union building in central Belfast, and acknowledges help in organising its events from the Fellowship of Messines, which is similarly made up of 'a diverse range of individuals from Loyalist, Republican and Trade Union backgrounds, united in their realisation of the necessity to confront sectarianism in our society as a necessary means to realistic peace building' (B.U.R.C. 2019). Similarly, the IBCC seeks to integrate all communities by commemorating a period of time in which the Belfast trade union and labour movements campaigned on a non-sectarian basis against the hardships and unemployment of the 1930s, a period which culminated in an unusual non-sectarian march of a group of Belfast workers to the 1934 Wolfe Tone commemoration in Bodenstown. As the burial site of the aforementioned Irish revolutionary, 
Bodenstown Cemetery had been the focal point of annual visits by various republican groups to commemorate his death in June of almost every year since 1873; the rare presence in 1934 of the non-sectarian trade union group, including Protestants and communists carrying a 'Break the connection with capitalism' banner, was also depicted in a 2013 mural in Belfast (I.R.S.P., 2013).

The IBCC’s cross-community support stance is reflected by its sources of funding and the diversified locations of its commemorative activities, plaques and monuments, which are spread across the west, east, north and centre of a city in which the Falls Road and Shankill Road areas have long been internationally known for the miles of 'peace lines' and high barriers that separate them.

We wish to acknowledge people and organisations who gave support to the IBCC in various forms. This includes the Falls Road Library, the Shankill Road Library, the Greater Shankill Partnership, the John Hewitt Bar, the Fellowship of Messines Association, Craigavon Trades Council, Sunflower Bar, ICTU [Irish Congress of Trade Unions] Youth Committee, Féile an Phobail the People’s Festival, the International Brigades Memorial Trust, Belfast Unemployed Resource Centre, the Dockers Club, ICTU, Shankill Women’s Centre (...) (IBCC 2015)

Created in 2005 around these cross-community objectives, the IBCC hosted a book launch for Bob Doyle’s Brigadista memoir in 2006, then attempted to set up its first small monument in a public space in Belfast. According to Ciaran Crossey, this was a difficult process as the City Council and its subsidiary body, the Laganside Development Corporation, were reluctant to accept a memorial to the International Brigades on Customs Square, a riverside site that once hosted mass political meetings but was being targeted for commercial redevelopment. After months of negotiations, a 'temporary' compromise was reached, and the monument was placed in a less frequented location.

Eventually we got in touch with some local political parties and a government department, who owns Writers' Square, the department of Social Development, they said yes you can put it up, for a few years, but it's still there. Twelve years later. But we had to get it literally concreted in. We had the AGM of the IBMT coming up [in 2007], so we just literally put it on the ground, the auld boys [International Brigade veterans] unveiled it, and then they went to the AGM, and as everybody went to the AGM we went and stored it in the union offices in Donegall 
Street. And then the following year we had another, a second round of unveilings, when it was literally set in stone. (Crossey interview 7 September 2018)

The IBCC's awareness of the need for cross-community work in a once conflict-ravaged city, combined with its growing experience of negotiating for funds and support, led to a more ambitious artistic project that aimed to symbolically inscribe long-marginalised working-class communities into the City Hall, in line with Belfast City Council's policy of reducing the unionist symbolic dominance over City Hall.

You see, the row where our window is, they're all social history windows, it's part of the movement to demilitarise, de-unionise [and de-sectarianise] City Hall. Making it that it's no longer just a unionist city hall. Everything up to the 1980s was unionist, the Queen’s photograph, memorials to the war down the side. And there's been a steady move to liberalise. And causes like ours come along, and we were persistent about it.

Crossey and the IBCC's efforts finally came to fruition in an unveiling ceremony on $24^{\text {th }}$ November 2015 with the Lord Mayor of Belfast, a number of International Brigaders' relatives, representatives from the Madrid AABI and the London IBMT and Irish musician and songwriter Andy Irvine. The commemorative booklet (IBCC 2015) contains transcripts of the speeches made on the night, which like a number of IBCC events described the Belfast Brigaders as visionaries who had hoped to forestall a second world war with fascism by defeating it in Spain. Unlike in the Republic of Ireland, support for the Spanish Republic had been widespread in Belfast due to the Catholic Church's lack of political power. The stainedglass window itself features the names of the major battles, a map of Spain and the ubiquitous 'No Pasarán', but also graphical references to Picasso’s Guernica, to 1930s Belfast, hunger marches and the 1940 Blitz, which as Crossey pointed out to me, could have been prevented if the International Brigades had been successful.

Despite this commitment to broad-based cross-community politics, one of the IBCC's other memorial projects still proved controversial. A proposed plaque to William Tumilson in the Short Strand district in East Belfast was quickly removed in 2013 after anonymous threats from the local loyalist paramilitaries, paraphrased by Crossey as 'if you don't remove the plaque, we'll remove the wall.' 


\section{A Continuing Relevance of Anti-Fascism in the Midst of Cultural and Digital Transitions.}

Impermanence and ephemerality of memory in Northern and southern Irish commemorations come in many forms beyond the difficulties of negotiating for, erecting and maintaining the physical memorials. Over the years, several Spanish Civil War-themed murals have been painted or installed on boards on the famous peace walls in West Belfast, many of which are replaced regularly. A visit to the walls in 2018 with Gerard Murray of the Teach na Fáilte Belfast Memorial Committee showed that although others have been removed, his mural has stayed on the wall since 2014. As we mentioned above, it reminds locals about the exceptional non-sectarian march from Belfast to the Wolfe Tone commemoration in Bodenstown in 1934, which in their eyes was a harbinger of similar non-sectarian support of the Spanish Republic in 1936. Perhaps because the East Belfast plaque mentioned above did not stay long, Murray’s 'mural' was printed on detachable boards so it could be easily moved elsewhere if it attracted problems or needed to be replaced.

What happened to it once was the wind caught it, and pulled it off. We thought it was damaged, but when we got the fella down to look at it, he says no, it's the wind that's caught it. Because they're on walls and the walls obviously aren't very good... But whether this one stays, that's up to me. (...) It means that if anything happens to that wall I can move it then and put it somewhere else. What we do is we get an artist to do what we want first, and then bring it to the fella who enlarges it and puts it on. (6 September 2018)

Unlike initiatives run by Belfast City Council, the painting of murals on International Wall is still coordinated by various republican groups, who probably see value in the rising number of tourists visiting the area and regularly renew this aspect of their discourse. According to Ciaran Crossey, there were previously two other murals on the main section of the Falls Road peace wall, one of which was noted in the January 2008 issue of the IBMT Newsletter.

There were two other wall murals on the International wall, in 2007 or 2008: one on the International brigades and one about Guernica. That wall has a high turnover, you get 6 months and then you get recycled. I don't know how they do it. Most of that main wall is dominated by the Provisionals, there's a couple of other groups, but the Provos they just recycle. 
The International Wall murals are not the only ones with short lifespans. In 2012, a large mural dedicated to Bob Doyle was installed on the façade of the Cobblestone Pub in Stoneybatter, north Dublin, 'as part of events to mark the 21st anniversary of Anti-Fascist Action (AFA) in Ireland' (Moloney 2012). In a September 2018 interview with its creator, Tommy Rash, he explained it had been removed after a complaint from neighbours.

There was some problem, I'm not sure, the council or something. When we unveiled the painting, this South American guy came up and was giving me abuse. He asked who is this, and we were like, well, he was a communist guy and he fought in the Spanish Civil War but yer man, I guess he just hated communists... As an artist, it's one of the best things I've ever done, I'm really proud of it... Me and Harry [Owens] need to find a new place for it. People come to the pub wanting to see it!

The digital form of this ephemerality of memory is just as pervasive. Although many of the local memorial groups in Ireland started out with a basic website for coordination purposes, many of them have either seen their hosting expire (such as the North West Spanish Civil War project in Derry), or else become less active with most activity moving to Facebook and social media. The Derry group's website is only partially accessible through the Internet Archive, reminding us that although the internet can give an illusion of permanence, its content can vanish if no one maintains the websites, leaving a gap where there was once a memorial resource. In this light, the survival of Ciaran Crossey's 'Ireland and the Spanish Civil War' documentation website, that has migrated from Tripod to Lycos, then to Yahoo's Geocities before gaining its own domain, has been both a small miracle but also the bane of academic works that refer to previous versions of the website and have fallen victim to link rot.

Whether due to lack of funds, loss of motivation or convenience, this second digital transition of Irish commemorations of the Spanish Civil War has been a retreat onto large platforms and social networks such as Facebook and YouTube, highlighting the commemorations' nature as a social activity as much as a political forum. Some FIBI visits to memorial sites have become 'express commemorations', taking place for photos, videos and a quick song, seemingly above all for social media sharing among peers, such as when a large group visiting the Ebro battlefields in 2018 stopped briefly at an anonymous building in Barcelona to remember Sligo nurse Hannah Ruth Ormsby, who died there in 1938 (FIBI 2018). ${ }^{10}$ They also use YouTube as a repository to store and share documentaries of interest, which are more vulnerable to copyright claims from the rights holders if found than a version 
videotaped from television. Many of their blogs and sites contain dead embedded links to Cathal O’Shannon's 1976 RTÉ documentary, Even the Olives are Bleeding, which has repeatedly been removed from YouTube on such grounds (and re-uploaded to Vimeo as of June 2019). The documentary is largely made up of interviews with Irish veterans who had supported both sides in the Spanish Civil War, alongside explanatory footage about the political turmoil in 1970s Spain.

Thus, some aspects of the digital transition represent a loss of control over the memorial groups' means of self-documentation and exchange. Despite the advantages of digital production methods, physical objects such as the commemorative booklets can still be found in archives decades afterwards or digitised, whereas typical social media posts disappear quickly down a timeline never to be seen again, irretrievable without a permalink even if they haven't been removed or blocked by new permissions systems. Underlining the ephemeral state of cultural activity, Hany Salah Eldeen and Michael L. Nelson have analysed this phenomenon of digital attrition using a dataset of social media posts on six topics of international relevance from 2009 to 2012, pointing out a steady loss of the form of memory social media posts often represent.

By analysing six different event-centric datasets of resources shared in social media in the period from June 2009 to March 2012, we found about 11\% lost and 20\% archived after just a year and an average of $27 \%$ lost and $41 \%$ archived after two and a half years. Furthermore, we found a nearly linear relationship between time of sharing of the resource and the percentage lost, with a slightly less linear relationship between time of sharing and archiving coverage of the resource. $(2012,1)$

If commemoration is more of a social and political activity in the present, this lack of permanence is less of a problem, such as for FIBI's core group of socialist republicans, who lived through the Troubles. To them a focus on the present, Spain and Irish points of view on the International Brigades come front and centre, reflecting both a transition to peaceful political activity but also a continuing wariness of spreading more information than necessary. Ó Machail explains thus that as an Irish-language activist and community organiser with a communist background, he joined FIBI as Public Relations Officer as he felt that the Charlie Donnelly Winter Schools and other commemorative events undertaken by FIBI had high social value, and that highlighting the International Brigades' many versions of socialism and antifascism had a strong relevance to the present political context they found themselves in. 
The original group was incredibly close-knit and possibly appeared to the outsider as an ephemeral and somewhat insular organisation. As the organisation has expanded, we have produced more newsletters and social media articles and conducted more interviews with the media in Ireland and Spain. However, as the threat from the continuing growth of the far right in Europe (not to mention the intelligence agencies of right wing governments in Ireland and Britain) is a real-time threat, it is understandable that prominent members should be wary about operating openly in the public sphere. Many FIBI members have experienced the harsh realities of state repression in the past and have sacrificed much in their lifetime of struggle against imperialism.

With its growth in membership, FIBI has been reaching out to younger and less politically engaged generations, most notably via a Spanish Civil War essay competition organised by a number of members. Run mostly by Harry Owens and FIBI members' contacts in the teaching profession, it was a relative success despite the small size of the organisation, which limited outreach capacity. Spanish historian and AABI organiser Severiano Montero Barrado noted in a Madrid republican periodical (Crónica Popular 18 February 2013) that FIBI had modelled the essay competition on that of American sister association ALBA (Abraham Lincoln Brigades Archive, New York), and invited 'the young winner, Eoin McDonald [over to Spain, where] he read out his essay with a recognisable Irish accent and convinced the audience with his lucidity. ${ }^{11}$ Having lapsed after 2014 due to upcoming organisational pressures of the multiple $80^{\text {th }}$ anniversary commemorations of battles (Lopera, Jarama, Brunete, Ebro and various events in Ireland), the essay competition was scheduled to return in 2019-2020.

\section{Conclusion}

Overall, this article contends that although the Irish are but one of many national commemoration groups to visit Spain regularly (mostly through FIBI), they are one of the most active compared to the size of their national population, and one of the more recent and intriguing manifestations of a continuing left-wing fascination with the Spanish Civil War. Since 1979, mainly following Bob Doyle’s unconventional activity initially but later developing their own relationships, they appear to have developed a unique perspective on the 
Spanish Civil War. Whereas the majority of European memorials to the International Brigades are collective, Irish commemorations seem to draw from their (often) republican roots by commemorating specific individuals in their places of origin. Where France, Great Britain, Germany and Italy had active veteran associations of International Brigaders long before them, the creation of the Friends of Charlie Donnelly in 1986 was as much a response to current events as a realisation that a corner of Irish history had been forgotten, despite its relevance to contemporary issues:

The politically aware have always opposed wealth and privilege and that night [the founding event in October 1986] the brigaders ${ }^{12}$ referenced the San Patricios who fought for Mexico in 1848 against US imperialism; the Citizen Army who took on the might of an empire in 1916; right up to the Irish then working with the Coffee Brigades to support Nicaragua's Sandinista government in their struggle against the US-backed Contra attacks. (FIBI, 2019)

But are the Irish commemorations of Spanish Civil War inwardly focused on the Irish themselves? Is Elisabetta Viggiani right, in a book about Northern Irish Troubles commemoration practices (2014: 2) that also acknowledged a great deal of help from Gerard Murray and Teach na Fáilte, to quote Nora’s observation that “Through the past, we venerate above all ourselves”? It is important to emphasise that despite the various locations in which they are based, the members of all the Irish local associations including FIBI, the IBCC, and others in Derry, Clare, Limerick, Waterford and all over the island are familiar with each other's activities and often turn up at each other's commemorations. Thus the encounter between distinctly Irish forms of remembrance such as mural painting and songwriting on the one hand and the cultural shock of half-forgotten Spanish Civil War history on the other, particularly through work with Spanish groups, has become a small piece of the edifice of cross-community reconciliation in Ireland, and fed the determination of all types of anti-fascist groups on both sides of the border to bond over what each see as their political struggles in a post-Troubles island. 
The author joined Friends of the International Brigades Ireland in 2017 to follow and understand their commemorative activities. In-person or phone interviews were held with FIBI and AABI members Gearoid Ó Machail, Gerard Murray, Harry Owens, Ciaran Crossey, and José Manuel Castro Fernandez. 'The Aigues-Mortes affair illustrates to the highest degree what I called in Le Creuset Français the "non-sites of memory" of the French republic's history. The "pogrom" and the denial of justice that followed it have been suppressed from our national memory, but also from local memory. As the collective work of "repentance" was never able to happen, there is still a latent sense of guilt even today in Aigues-Mortes, as I realised when I was researching the topic there.' The Dutch memorial association, Stichting Spanje 1936-1939, has coordinated a map of all the Spanish Civil War-related monuments in the world. See: Stichting Spanje 1936-39. 2015. 'Gedenktekens Memorials - Gedenkstätten - Mémoriaux - Memoriales’. Spanje 36 - 39 (blog). 26 October 2015. https://spanje3639.org/educatie/gedenktekens-memorials-gedenkstatten-memoriaux-memoriales/. The ambitious project has since been abandoned due to political difficulties and its website, http://amigce.org/, has gone offline, but remains accessible via the Internet Archive. See Dunne 2006.

6 International Brigade Commemoration Committee, Belfast.

7 'Our relationship with the Irish is very good, because their work helps the town of Rivas. It's not only a memorial to Charlie and to the International Brigades, but also a place of interest to residents and to tourists, I'd say. Our work together also led FIBI to invite the town council members to a conference in 2017, and so I went to the Charlie Donnelly [Winter] School, as a representative of the town council.' Interview with José Manuel Fernandez Castro, 28 February 2019. Interview with E.R. (AABI), 16 February 2019.

$9 \quad$ Irish Republican Socialist Party, originally a breakaway group from the Official Sinn Féin with an aligned armed wing which declared a ceasefire in 1998. A number of IRSP members have installed plaques in Belfast and participated in FIBI events, including Gerard Murray.

10 The author was present on this visit, as a FIBI member. She has been documented in various recent Irish news articles such as Murphy, Pauline. 2017. "Sligo Nurse’s Role in Spanish Civil War Recalled.” The Sligo Champion, March 11, 2017.

$<$ https://www.independent.ie/regionals/sligochampion/lifestyle/sligo-nurses-role-in-spanish-civil-warrecalled-35506786.html>.

11 'Harry Owens, de la FIBI (...) ha promovido el Primer Concurso escolar de ensayos sobre las BI. Explicó que la idea surgió de la competición que todos los años se hace en los EEUU [United States] fomentada por ALBA (Abraham Lincoln Brigade Archives) y animó a que la idea se vaya extendiendo. De momento este curso el resultado ha sido brillante, ya que el joven ganador, Eoin McDonald, leyó su trabajo con su reconocible acento irlandés y convenció al auditorio por su lucidez’ (Crónica Popular, 18 February 2013).

12 At least three International Brigade veterans were present at the event in August 1986, including Michael O’Riordan, Bob Doyle and Peter O’Connor. 


\section{References}

Belfast Executive of Republican Clubs. 1975. No Pasaran!: The Story of the Irish Volunteers Who Served with the International Brigades in Defending the Spanish Republic Against International Fascism 1936-1938. Belfast: self-published.

Belfast Unemployed Resource Centre (B.U.R.C.). 2017. “Fellowship of Messines.” November 14. http://www.burc.org/what-price-citizenship/.

Boikot. 2017. Jarama (Videoclip Oficial). Rivas-Vaciamadrid. https://www.youtube.com/watch? $\mathrm{v}=4 \mathrm{zOuOMvXghA}$.

De Bréadún, Deaglán. 1986. “Spanish Civil War Fighters Recalled on Achill.” Irish Times, September 8. http://irelandscw.com/part-ITAchill1986.htm.

Campelo, Patricia. 2017. ““Sólo En Belfast Hay Más Homenajes a Los Brigadistas Internacionales Que En España”.” Público. http://www.publico.es/culturas/belfast-hay-homenajesbrigadistas-internacionales.html.

Doyle, Bob, and Owens, Harry. 2006. Brigadista: An Irishman’s Fight against Fascism. Blackrock: Curragh Press.

Dunne, Ryan. 2006. “Charlie Donnelly Winter School 2006.” Culture Northern Ireland (blog). March 10. https://www.culturenorthernireland.org/article/1532/review-charlie-donnellywinter-school-2006.

“Even the Olives Were Bleeding.” 2010. Andersonstown News, 8 March: 19.

Friends of the International Brigades Ireland. 2018. La Lucha Continua. Dublin: self-published.

Friends of the International Brigades Ireland. 2019. "What We're About.” http://fibi-ireland.com/about/

Gernika 80 Committee. 2017. Gernika Then and Now: 80 Years of Basque-Irish anti-fascist struggles. Dublin: self-published via Grehan Print.

Higgins, Michael D. 2016. “Speech of the President at IBMT AGM, 2016.” Áras an Uachtarain (Office of the President). October 15.

$<$ http://www.president.ie/en/media-library/speeches/speech-at-the-opening-of-theinternational-brigade-memorial-trust-agm.>

I.R.S.P. (2013). “Teach Na Fáilte Unveil Mural to the XV International Brigade.” Irish Republican Socialist Party (blog). April 21. https://irsp.ie/1165/.

International Brigade Commemoration Committee (Belfast). 2015. Civil War in Spain: A Time of Heroes. Belfast: IBCC (with support from the NI Community Relations Council)

Limerick International Brigade Memorial Trust. 2014. From the Shannon to the Ebro: the Limerick Men who went to fight Franco. Limerick: self-published via JustPrint.ie. 'Memorials - Ireland | International Brigade Memorial Trust'. http://www.internationalbrigades.org.uk/memorials?tid=6. 
Marco, Jorge. 2016. “Legitimacy by Proxy: Searching for a Usable Past through the International Brigades in Spain’s Post-Franco Democracy, 1975-2015.” Journal of Modern European History 14 (3): 391-410. https://doi.org/10.17104/1611-8944-2016-3-391.

McGreevy, Ronan. 2019. "Local Authorities to Receive $€ 10,000$ Grant for Decade of Centenaries.” The Irish Times, March 11. https://www.irishtimes.com/news/ireland/irish-news/localauthorities-to-receive-10-000-grant-for-decade-of-centenaries-1.3821717.

Moloney, Mark. 2012. "Mural to Irish International Brigader and IRA Veteran Bob Doyle Unveiled in Dublin.” An Phoblacht, October 9. https://www.anphoblacht.com/contents/22330.

Montero Barrado, Severiano. 2013. “76ª aniversario de la batalla del Jarama - Crónica Popular.” Crónica Popular (blog). February 18. http://www.cronicapopular.es/2013/02/760aniversario-de-la-batalla-del-jarama/.

Noiriel, Gérard. 2006. Le creuset français: histoire de l'immigration, XIXe-XXe siècles. Paris: Seuil.

Noiriel, Gérard. 2010. “De l’Aube Jusqu'à l’Aurore: Aigues-Mortes, 17 août 1893.” Document de travail, réalisé avec le soutien de La Cité Nationale de l'Histoire de l'Immigration, dans le cadre des recherches menées en vue de la publication de l'ouvrage Le massacre des Italiens, Aigues-Mortes, 17 août 1893, Ed. Fayard, janvier 2010. https://www.histoireimmigration.fr/collections/aigues-mortes $>$.

Nora, Pierre. 1989. “Between Memory and History: Les Lieux de Mémoire.” Representations, 26: 7-24.

O’Connor, Emmet. 2008. “Identity and Self-Representation in Irish Communism.” Socialist History 34: 36-51.

O’Shannon, Cathal. 1976. Even the Olives Are Bleeding. The Irish in the Spanish Civil War. Dublin: R.T.E.

Richart, Fran. 2019. “L’ADN d’un milicià irlandès podria revelar un episodi inèdit de la Guerra Civil a l’Ebre.” Imagina Ràdio, March 6. < http://www.imaginaradio.cat/ladn-dun-miliciairlandes-podria-revelar-un-episodi-inedit-de-la-guerra-civil-a-lebre/.>

Salah Eldeen, Hany M., and Nelson, Michael L. (2012). "Losing My Revolution: How Many Resources Shared on Social Media Have Been Lost?” Theory and Practice of Digital Libraries. Eds. Panayiotis Zaphiris, George Buchanan, Edie Rasmussen and Fernando Loizides. Berlin, Heidelberg: Springer. 125-137.

Stichting Spanje 1936-39. 2015. “Gedenktekens - Memorials - Gedenkstätten - Mémoriaux Memoriales.” Spanje 36 - 39 (blog). Oct. 26. May 302019.

$<$ https://spanje3639.org/educatie/gedenktekens-memorials-gedenkstatten-memoriauxmemoriales $/ \geq$.

Stichting Spanje 1936 - 1939, ALBA, AABI, FIBI, IBMT, et al. 2015. "Spanish Civil War Memorials.” Google My Maps. Accessed 30 May 2019.

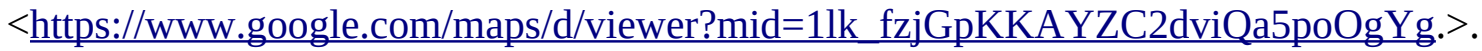

Viggiani, Elisabetta (2014). Talking Stones: The Politics of Memorialization in Post-Conflict Northern Ireland. New York: Berghahn Books. 